\title{
PERAN KOMISI PENYIARAN INDONESIA DAERAH YOGYAKARTA DALAM MENJALANKAN FUNGSI SEBAGAI REGULATOR DAN PENGAWASAN PENYIARAN TELEVISI DAERAH ISTIMEWA YOGYAKARTA
}

\author{
Abi Hamdalah ${ }^{1}$, Sunarno ${ }^{2}$ \\ ${ }^{1,2}$ Program Studi Hukum, Fakultas Hukum, Universitas Muhammadiyah Yogyakarta, Indonesia \\ Jl. Brawijaya, Tamantiro, Kasihan, Bantul, Yogyakarta \\ E-mail: 'abi.hamdalah.2015@law.umy.ac.id; ${ }^{2}$ sunarno@umy.ac.id
}

\author{
Info Artikel \\ Diajukan: 16-11-2019 \\ Direview: 14-12-2019 \\ Direvisi: $31-12-2019$ \\ Diterima: $31-12-2019$
}

DOI: 10.18196/mls.1103

\begin{abstract}
Abstrak
Perkembangan media massa terutama pertelevisian ini tentu ada yang menimbulkan dampak negatif terhadap sosial budaya masyarakat maka pemerintah mengatur tentang penyiaran dalam bagian kedua penyelenggaraan penyiaran Pasal 8 ayat (1) Undang-Undang nomor 32 tahun 2002 tentang Penyiaran yaitu KPI sebagai wujud peran serta masyarakat berfungsi mewadahi aspirasi serta mewakili kepentingan masyarakat akan penyiaran, dan ayat (2) point c yaitu mengawasi
\end{abstract} pelaksanaan peraturan dan pedoman perilaku penyiaran serta standar program siaran. KPI/KPID mengatur segala aspek penyiaran di Indonesia.Siaran di televisi kerap kali menayangkan berita-berita yang mengandung unsur pornografis, kekerasan, hedonisme, dan sebagainya yang ditampilkan di layar kaca. Dalam penyelenggaraan pengawasan penyiaran KPID DIY melakukan pemantauan langsung yang dilakukan oleh tenaga ahli lembaga penyiaran selain itu KPID DIY sendiri mempunyai alat record untuk memantau seluruh aktifitas penyiaran baik itu televisi maupun radio di wilayah Yogyakarta selama 24 jam, yang apabila terdapat suatu pelanggaran KPID dapat melihat pelanggaran itu dengan sangat mudah melalui alat tersebut. Penjatuhan Sanksi dari KPID DIY yaitu Program siaran yang terbukti secara sah dan meyakinkan melanggar Standar Program Siaran dijatuhkan sanksi administratif oleh KPID. Kewenangan KPI/KPID DIY sebagai lembaga negara independen tidak tercermin dalam UU No. 32 Tahun 2002 tentang penyiaran, dimana peran KPI dalam merumuskan Peraturan Pemerintah tentang penyiaran dihapus oleh Mahkamah Konstitusi. Selain itu secara kelembagaan KPID DIY masih berada di bawah Dishubkominfo. Anggaran KPID DIY juga masih kecil sehingga berpengaruh juga pada kurangnya fasilitas pengawasan yang dimilikinya. Kata kunci: efektifitas, pengawaasan, penyiaran.

\section{Pendahuluan.}

Sejak bergulirnya reformasi, wajah lembaga penyiaran berubah total seperti yang dirasakan saat ini. Lembaga penyiaran, khususnya televisi dan radio bagai menemukan dunia yang baru dalam fungsinya sebagai transformasi pendidikan, informasi dan sebagai hiburan bagi masyarakat. Televisi dalam perkembangannya bukan lagi menjadi barang mewah serta stasiun televisi tidak lagi didominasi oleh perusahaan besar saat ini televisi semakin dekat dengan penonton dan sumber beritanya. 
Penyiaran televisi adalah media komunikasi massa dengar pandang yang menyalurkan gagasan dan informasi dalam bentuk suara dan gambar baik secara tebuka dan tertutup berupa program yang teratur dan berkesinambungan.

Kemerdekaan menyatakan pendapat, menyampaikan, dan memperoleh informasi, bersumber dari kedaulatan rakyat dan merupakan hak asasi manusia dalam kehidupan bermasyarakat, berbangsa, dan bernegara yang demokratis. Dengan demikian, kemerdekaan atau kebebasan dalam penyiaran harus dijamin oleh negara. Dalam kaitan ini Undang-Undang Dasar Negara Republik Indonesia Tahun 1945 mengakui, menjamin dan melindungi hal tersebut. Namun, sesuai dengan cita-cita Proklamasi Kemerdekaan Indonesia, maka kemerdekaan tersebut harus bermanfaat bagi upaya bangsa Indonesia dalam menjaga integrasi nasional, menegakkan nilai-nilai agama, kebenaran, keadilan, moral, dan tata susila, serta memajukan kesejahteraan umum, dan mencerdaskan kehidupan bangsa. Dalam hal ini kebebasan harus dilaksanakan secara bertanggungjawab, selaras dan seimbang antara kebebasan dan kesetaraan menggunakan hak berdasarkan Pancasila dan Undang-Undang Dasar Negara Republik Indonesia Tahun 1945.

Setiap daerah mempunyai Visi pembangunan untuk menjadikan daerahnya maju dan berkembang sesuai dengan kebutuhan masyarakat di daerahnya masing-masing. ${ }^{1}$ Televisi (TV) lokal sebagai lembaga penyiaran di daerah, dituntut mampu menerjemahkan dan menyukseskan amanah otonomi daerah dengan mengembangkan konten-konten positif berbasis kearifan lokal daerah untuk pengembangan dan pembangunan daerah. Paket tayangan yang bermaterikan sosial, budaya, pariwisata, ekonomi, dan unsur kedaerahan menjadi suatu kebutuhan bagi seluruh lapisan masyarakat dalam upaya optimalisasi pembangunan daerah. Sehingga kehadiran televisi lokal, menjadi solusi penting untuk hal tersebut. ${ }^{2}$

Siaran di televisi kerap kali menayangkan berita-berita yang mengandung unsur pornografis, kekerasan, hedonisme, dan sebagainya yang ditampilkan di layar kaca. Berita tersebut disaksikan oleh berbagai lapisan masyarakat, diantaranya adalah anakanak dan remaja. Mereka masih belum dapat memilih dan memilah mana tayangan yang seharusnya patut dicontoh dan tidak. Tayangan berita yang demikian dapat mempengaruhi perilaku anak-anak dan remaja yang notabene masih berjiwa labil.

Dalam Undang-undang No.32 tahun 2002 tentang Penyiaran telah dijelaskan serta diatur tentang hal-hal yang dilarang menjadi sebuah tayangan penyiaran televisi yang mana Pasal 36 berbunyi:

\footnotetext{
${ }^{1}$ Yantos. "Peranan Lembaga Penyiaran Publik Lokal Dalam Mendukung Pemerintah Daerah". Jurnal Risalah, Vol.26 No.2, 2015, hlm 95

${ }^{2}$ Rifka S. Akibu, "Implementasi Kebijakan Perizinan Penyiaran Televisi Lokal di Provinsi Gorontalo", Jurnal Ilmu Administrasi, Vol.4 No.2, 2015, hlm 1
} 
1) Isi siaran wajib mengandung informasi, pendidikan, hiburan, dan manfaat untuk pembentukan intelektualitas, watak, moral, kemajuan, kekuatan bangsa, menjaga persatuan dan kesatuan, serta mengamalkan nilai-nilai agama dan budaya Indonesia.

2) Isi siaran dari jasa penyiaran televisi, yang diselenggarakan oleh Lembaga Penyiaran Swasta dan Lembaga Penyiaran Publik, wajib memuat sekurang-kurangnya 60\% (enam puluh per seratus) mata acara yang berasal dari dalam negeri.

3) Isi siaran wajib memberikan perlindungan dan pemberdayaan kepada khalayak khusus, yaitu anak-anak dan remaja, dengan menyiarkan mata acara pada waktu yang tepat, dan lembaga penyiaran wajib mencantumkan dan/atau menyebutkan klasifikasi khalayak sesuai dengan isi siaran.

4) Isi siaran wajib dijaga netralitasnya dan tidak boleh mengutamakan kepentingan golongan tertentu.

5) Isi siaran dilarang :

a. bersifat fitnah, menghasut, menyesatkan dan/atau bohong;

b. menonjolkan unsur kekerasan, cabul, perjudian, penyalah-gunaan narkotika dan obat terlarang; atau

c. mempertentangkan suku, agama, ras, dan antargolongan.

6) Isi siaran dilarang memperolokkan, merendahkan, melecehkan dan/atau mengabaikan nilai-nilai agama, martabat manusia Indonesia, atau merusak hubungan internasional.

Komisi Penyiaran Indonesia Daerah Yogyakarta harus mempunyai cara dan strategi dalam mengawasi penyiaran acara televisi. Cara-cara yang digunakan dalam melakukan pengawasan tentu harus mempertimbangkan dan memperkirakan faktorfaktor penghambat yang akan maupun telah dihadapi.

\section{Metode Penelitian}

Jenis penelitian dalam penelitian ini adalah hukum normatif dan empiris dimana dilakukan penelitian terhadap studi kasus yang kemudian membahasnya dengan menggunakan bahan bacaan yang diperoleh dari berbagai sumber. Penelitian yang meneliti kaidah atau aturan hukum sebagai suatu bangunan sistem yang terkait dengan suatu peristiwa hukum. Dalam hal ini penulis meneliti bagaimana peran KPID dalam pengawasan penyiaran di daerah Yogyakarta. Bahan hukum yang digunakan terdiri dari bahan hukum primer yakni perundang-undangan terkait yaitu Undang-Undang Dasar 1945, Undang-undang No. 40 Tahun 1999 tentang Pers, Undang-undang No. 32 Tahun 2002 tentang Penyiaran, Undang-undang No.14 Tahun 2008 tentang Keterbukaan Informasi Publik Pedoman Perilaku Penyiaran (P3) dan Standar Program Siaran (SPS), Peraturan Daerah Daerah Istimewa Yogyakarta Nomor 13 Tahun 2016 Tentang Penyelenggaraan Penyiaran, Peraturan Gubernur Daerah Istimewa Yogyakarta No. 37 Tahun 2017 tentang Fasilitasi Pembentukan Lembaga Penyiaran Komunitas, Peraturan 
Gubernur DIY No. 38 Tahun 2017 tentang Tata Cara Pengenaan Sanksi Administrasi dan Pemberian Penghargaan atas Penyelenggaraan Penyiaran Sistem Stasiun Jaringan Oleh Lembaga Penyiaran Swasta Jasa Penyiaran Televisi. Sedangkan bahan hukum sekunder terdiri dari rancanan undang-undang, hasil-hasil penelitian, hasil karya dari kalangan hukum dan lainnya. Kemudian bahan hukum tersier adalah kamus, ensiklopedia, indeks kumulatif dan seterusnya. Analisis data penelitian ini menggunakan metode deskriptif yaitu bahan hukum digambarkan dan diuraikan berupa kalimat yang teratur, runtun, logis, dan efektif. Hal ini untuk mendapatkan suatu gambaran dan kesimpulan yang benar dan akurat dalam menjawab permasalahan yang telah dirumuskan. Untuk lokasi penelitian terletak di Komisi Penyiaran Indonesia Daerah Yogyakarta.

\section{Hasil Penelitian dan Analisis}

\subsection{Pengawasan Komisi Penyiaran Indonesia Daerah Yogyakarta Dalam penyiaran Televisi Daerah Yogyakarta}

Media massa dalam cakupan komunikasi massa yaitu surat kabar,majalah, radio dan televisi. ${ }^{3}$ Selain itu media massa sebagai produk teknologi modern yang selalu berkembang, salah satu media massa yang berkembang saat ini adalah televisi. Televisi berarti suatu sistem penyajian gambar berikut suaranya dari suatu tempat yang berjarak jauh. ${ }^{4}$ Sebagai salah satu alat dari komunikasi pemerintah, televisi juga mempunyai pesan tersendiri terhadap suatu kondisi sosial budaya pada suatu bangsa. ${ }^{5}$ Disamping itu, teknologi komunikasi juga membuat produk komunikasi mempunyai standarisasi. Standarisasi produk ini merupakan dampak tak terelakkan dari industrialiasi media, mekanisasi, urbanisasi, dan redistribusi pendapatan. ${ }^{6}$ Kepemilikan yang telah dipegang serta pengendalian media yang dilakukan dapat mempengaruhi isi media dan isi media itu sendiri juga dapat menentukan pengaruh media dalam masyarakat. ${ }^{7}$

Komisi Penyiaran Indonesia (KPI) adalah lembaga yang bersifat independen yang di bentuk melalui Undang-undang Nomor 32 Tahun 2002 tentang penyiaran dengan tujuan mengatur segala hal tentang penyiaran di Indonesia. Lahirnya UndangUndang Penyiaran No. 32 tahun 2002 lebih dikarenakan tuntutan reformasi termasuk didalamnya reformasi dunia penyiaran yang menempatkan publik sebagai pemilik dan

${ }^{3}$ Onong Uchjana Effendy,M.A, Televisi Siaran Teori dan Praktek ,Mandar Maju, Bandung, Tahun 1993 Cetakan 2,hlm 15

${ }^{4}$ Sutisno P.C.S., Pedoman Praktis Penulisan Skenario Televisi dan Video (Jakarta: PT Grasindo, 1993), hlm. 1.

${ }^{5}$ Apriadi Tamburaka, Literasi Media, PT Rajagrafindo Persada,Jakarta, 2013 Cetakan 1, hlm 12

${ }^{6}$ Media, Sucahya "Teknologi Komunikasi dan Massa”. Jurnal Komunikasi Vol.2 No. 1, 2013, hlm. 8

${ }^{7}$ Werner J. Severin \& James W. Tankard,Jr, Teori Komunikasi, Kencana Prenada Media Grup,Jakarta, Tahun 2011, Cetakan 5, hlm 373 
pengendali utama ranah penyiaran. Dalam upaya mencegah hal tersebut, dibentuk dewan pers yang independen. Sehingga membuat media yang tidak dipengaruhi oleh berbagai kekuatan sosial, ekonomi maupun politik dan lebih mengedepankan transparansi informasi ke pada khalayak. ${ }^{8}$

Komisi Penyiaran Indonesia (KPI) adalah lembaga yang bersifat independen yang di bentuk melalui Undang-undang Nomor 32 Tahun 2002 tentang penyiaran dengan tujuan mengatur segala hal tentang penyiaran di Indonesia. Lahirnya UndangUndang Penyiaran No. 32 tahun 2002 lebih dikarenakan tuntutan reformasi termasuk didalamnya reformasi dunia penyiaran yang menempatkan publik sebagai pemilik dan pengendali utama ranah penyiaran. ${ }^{9}$

Lembaga Independen ini terdiri dari KPI Pusat dan KPID di daerah yang tugasnya bersifat koordinatif, kebijakan secara nasional di tentukan KPI sedangkan pelaksanaan di tingkat Provinsi menjadi cakupan KPID. Pembagian wewenang KPI dan KPID diatur oleh atau ditetapkan dengan Keputusan KPI yang dituangkan pada Salinan Keputusan Komisi Penyiaran Indonesia Nomor 005 Tahun 2004 tentang kewenangan, tugas, dan tata hubungan antara Komisi Penyiaran Indonesia Pusat dan Komisi Penyiaran Indonesia Daerah yaitu bahwa KPID menjalankan kebijakan KPI ditingkat daerah sesuai dengan peraturan perundang-undangan yang berlaku. Menjalankan fungsinya KPID memiliki kewenangan (otoritas) menyusun dan mengawasi berbagai peraturan penyiaran yang menghubungkan antara lembaga penyiaran, pemerintah dan mayarakat. Pengaturan ini mencakup semua daur proses kegiatan penyiaran, mulai dari tahap pendirian, operasionalisasi, pertanggungjawaban dan evaluasi. Dalam rangka menjalankan fungsinya KPI memiliki wewenang Pasal 8 Undang-Undang penyiaran. ${ }^{10}$ sebagai wujud peran serta masyarakat di bidang penyiaran, KPI/KPID DIY memeiliki wewenang menyusun dan juga mengawasi berbagai peraturan penyiaran yang menghubungkan antara masyarakat dengan Lembaga penyiaran. dalam menertibkan program siaran lokal maupun swasta.

1. Sejarah Komisi Penyiaran Indonesia Daerah

Komisi Penyiaran Indonesia Merupakan suatu Lembaga Negara Independen yang dibentuk dan diatur Melalui Undang-undang No 32 Tahun 2002 tentang Penyiaran dengan tujuan utama yaitu untuk mengatur segala hal yang bersangkutan dengan penyiaran yang ada di Indonesia, KPI terdiri atas Komisi Penyiaran Indonesia Pusat disingkat KPIP dan juga Komisi Penyiaran Indonesia Daerah disingkat KPID, KPIP

\footnotetext{
${ }^{8}$ Eko Harry Susanto, "Media Massa, Pemerintah dan Pemilik Modal" Jurnal Komunikasi, Vol. 1 No. 6, 2013, hlm 478

${ }^{9}$ Miranda, Audina Fajriani."Pengawasan Konten Siaran Asing oleh Komisi Penyiaran Indonesia Daerah (KPID) Kepulauan Riau pada TV Kabel Berlangganan”, Jurnal Ilmu Pemerintahan Vol.3 No.1, 2018, hlm.13

${ }^{10}$ Febri, Eko Prasetyo, Peran Komunikasi Dalam Mengoptimalkan Komisi Penyiaran Indonesia Daerah (KPID) Provinsi Kalimantan Timur Dalam Melakukan Pengawasan Terhadap Lembaga Penyiaran di Samarinda, Jurnal Ilmu Komunikasi, Vol.5 No.4, 2017 hlm.41-55
} 
berada di Ibukota Negara RI, sedangkan untuk KPID berada di setiap Ibukota Provinsi di Indonesia.

Komisi Penyiaran Indonesia merupakan salah satu dari Lembaga Negara Independen, yang dimaksud dengan Lembaga Negara independen yaitu suatu Lembaga yang dalam menjalankan fungsi serta tugasnya dengan bebas dari campur tangan serta tekanan dari partai politik, pemerintah dan juga pihak-pihak lainnya yang mempunyai kepentingan khusus. Di Indonesia selain dari KPI ada juga . Lembaga Negara yang disebut dengan Lembaga Independen yaitu KPK (Komisi Pemberantasan Korupsi), BI (Bank Indonesia), Lembaga Peradilan Indonesia (Pengadilan, Kejaksaan dan Kepolisian), sebagai lembaga independen negara yang ada KPI memiliki 9 (Sembilan) orang anggota yang terbagi menjadi beberapa bidang kerja yaitu ketua, wakil ketua, bidang kelembagaan ada 3 anggota, bidang perizinan memiliki 2 anggota dan bidang isi siaran memiliki 4 anggota. Sedangkan untuk tingkat KPID DIY juga memiliki anggota komisioner, namun tidak sebanyak KPI pusat yang memiliki 9 anggota komisioner yaitu. sedangkan KPID DIY memiliki 7 anggota komisioner yang membawahi bidang kerja yang ada di KPID DIY, yaitu ketua merangkap bidang kelembagaan, wakil ketua merangkap bidang pengawasan isi siaran, koordinator bidang pengelolaan struktur dan sistem siaran, koordinator bidang kelembagaan, koordinator bidang pengawasan isi siaran, anggota bidang pengelolaan struktur dan sistem siaran, anggota bidang pengawasan isi siaran. Dalam pelaksanaan pengawasannya, KPID DIY mengawasi seluruh tayangan televisi yang ada di DIY, termasuk siaran televisi dari daerah lain seperti Jakarta yang relay di DIY. KPID DIY juga berwenang untuk memberikan sanksi kepada seluruh lembaga penyiaran yang melakukan pelanggaran siaran.

Dasar hukum yang digunakan KPID DIY dalam melakukan pengawasan siaran adalah Pedoman Perilaku Penyiaran dan Standar Program Siaran (P3SPS).KPID DIY kerap melakukan literasi media, diskusi publik, dan public hearing dengan berbagai pihak, khususnya kalangan akademisi di DIY.Hal ini adalah yang menjadi perhatian bagi KPID DIY dalam upayanya menjadikan masyarakat lebih melek media dan partisipatif dalam melakukan pengawasan terhadap siaran televisi. Pengawasan KPID DIY sangat mengandalkan alat perekam siaran televisi yang terdapat di laboratorium KPID DIY, karena masih rendahnya pengaduan dari masyarakat jika dibandingkan dengan potensi pelanggaran siaran. Selain itu KPID DIY juga membuka layanan pengaduan dari masyarakat melalui SMS, telepon, e-mail, faksimile, dan sosial media Facebook dan Twitter. Pedoman Perilaku Penyiaran dan Standar Program Siaran (P3SPS) sebagai dasar hukum sudah tidak relevan dengan perkembangan teknologi televisi, dengan adanya pasal-pasal yang tidak dapat mencegah terjadinya pelanggaran siaran seperti mekanisme pemberian sanksi yang tidak bertingkat. 
Gambar 1. Struktur Organisasi KPID DIY Periode 2017-2020

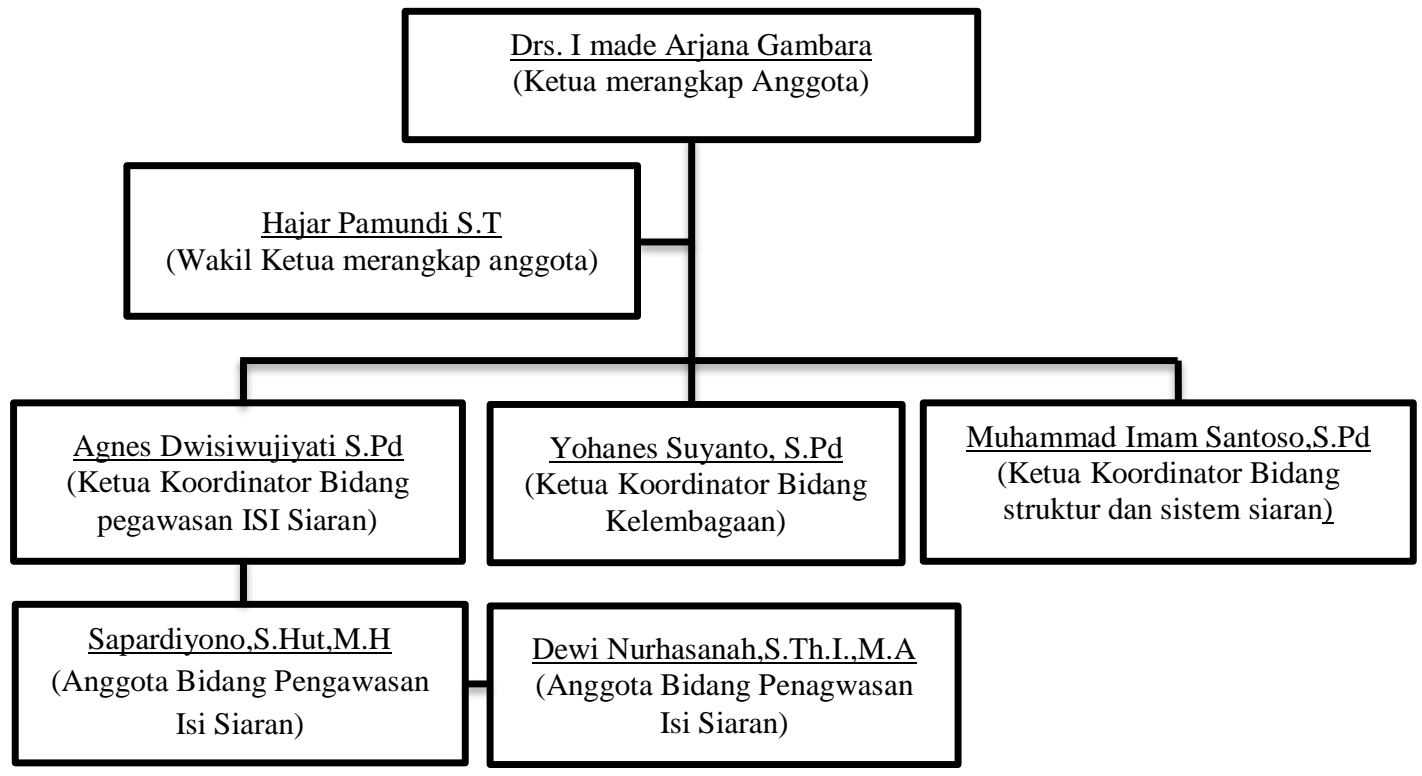

Sumber: dokumen KPID DIY

\section{Mekanisme Pengawasan oleh KPID}

Dalam penyelenggaraan pengawasan penyiaran KPID DIY melakukan pemantauan langsung yang dilakukan oleh tenaga ahli lembaga penyiaran selain itu KPID DIY sendiri mempunyai alat record untuk memantau seluruh aktifitas penyiaran baik itu televisi maupun radio di wilayah Yogyakarta selama 24 jam, yang apabila terdapat suatu pelanggaran KPID dapat melihat pelanggaran itu dengan sangat mudah melalui alat tersebut.

Keberhasilan implementasi kebijakan sangat tergantung dari kemampuan memanfaatkan sumber daya yang tersedia. Manusia merupakan sumber daya yang terpenting dalam menentukan keberhasilan suatu implementasi kebijakan. Setiap tahap implementasi menuntut adanya sumber daya manusia yang berkualitas sesuai dengan pekerjaan yang diisyaratkan oleh kebijakan yang telah ditetapkan. ${ }^{11}$

Untuk pengawasan isi siaran KPID DIY tidak bekerja sendiri dengan bersinergi kepada seluruh lapisan masyarakat, komunitas, media informasi dan perguruan tinggi, untuk sama-sama mewujudkan isi siaran yang sehat. KPID DIY dibantu juga dengan sekretariat untuk melakukan pelayanan teknis dan administratif kepada KPID dalam menyelenggarakan tugas, fungsi, dan wewenangnya.

Pengawasan dalam proses adalah pengawasan yang dilakukan ketika sedang terjadinya penyimpangan dengan maksud agar pelaksanaan selanjutnya sesuai dengan rencana. KPID Yogyakarta dalam melakukan pengawasan dalam proses adalah sebagai

${ }^{11}$ Akibu, Rifka S. "Implementasi Kebijakan Perizinan Penyiaran Televisi Lokal di Provinsi Gorontalo" Jurnal Ilmu Administrasi, Vol.4 No.2, 2015 hlm.66 
berikut:

a. Layanan Aduan

Fasilitas layanan aduan meruakan salah satu strategi KPID Yogyakarta yang dalam hal ini ditunjukan untuk memudahkan masyarakat ikut berpartisiasi dalam melakukan proses pengawasan. Bedasarkan data yang penulis dapat baik data sekunder maupun primer layanan aduan yang dibuat oleh KPID Yogyakarta yaitu dengan membuat akun facebook, website, telpon dan email. Dengan adanya fasilitas tersebut harapannya masyarakat dimudahkan ketika ingin berkomunikasi dengan KPID Yogyakarta.

\section{b. Pengawasan oleh Staf Pemantau}

Staf pemantau sendiri merupakan bagian KPID Yogyakarta yang langsung dikoordinir oleh komisioner koordinator pengawasan da nisi siaran. Staf Pemantau saat ini hanya ada di wilayah Kota Yogyakarta saja. Tugas Staf Pemantau adalah melakukan pemantauan langsung terhadap program siaran yang sedang berjalan. Dibandingkan jumlah lembaga penyiran yang lebih banyak dibandingkan staf pemantau yang hanya berjumlah 4 orang maka dilakukan strategi-strategi khusus, salah satunya menerapkan aturan 2 shift kerja (pagi dan malam). Selain itu untuk mengatasi lembaga penyiaran yang lebih banyak dipantau adalah sebagai berikut;

1) Staf pemantau hanya memantau lembaga penyiaran yang memiliki programprogram yang sangat rentan terjadinya pelanggar aturan atau program yang berjalan secara langsung atau live.

2) Staf pemantau hanya memantau program yang isinya produk-produk news baik itu televisi atau radio yang ada program beritanya

3) Staf pemantau hanya memantau program berupa program talk show

4) Staf pemantau hanya memantau program berupa program komedi atau candaancandaan

5) Staf pemantau hanya memantau program berupa program iklan khususnya iklan obat tradisional yang mengandung testimoni-testimoni penggunanya

6) Staf pemantau hanya memantau program berupa program musik. Beberapa lagu ada yang liriknya melanggar norma dan aturan yang berlaku.

Dibandingkan dengan layanan aduan yang ditujukan kemasyarakat dalam memberikan informasi aduan pelanggaran, staf pemantau jauh lebih efektif $80-90 \%$ temuan-temuan pelanggaran yang dilakukan lembaga penyiaran di Yogyakarta. Berdasarkan pengawasan dalam proses, apa yang sudah dilakukan oleh KPID Yogyakarta sudah sesuai agar pelaksanaan selanjutnya sesuai dengan rencana. Metode strategi komunikasi yang dilakukan bedasarkan pengawasan dalam proses ini KPID Yogyakarta menggunakan metode informatif dalam bentuk layanan aduan dan metode redundancy dalam bentuk pengawasan yang dilakukan oleh staf pemantau dimana pengawasan yang dilakukan diulang terus menerus. 
Pengertian pengawasan represif adalah pengawasan yang dilakukan sesudah terjadinya penyimpangan atau kesalahan-kesalahan dengan tujuan untuk memperbaiki dan agar kelak dalam pelaksanaan selanjutnya tidak menyimpang lagi. Dalam hal ini KPID Yogyakarta harus memastikan tindakan apa yang dilakukan ketika ada lembaga penyiaran di Yogyakarta yang melakukan kesalahan, sehingga dengan tindakan yang diambil tersebut diharapkan lembaga penyiaran dikemudian hari tidak melakukan pelanggaran kembali. Upaya-upaya yang dilakukan oleh KPID Yogyakarta dalam mengambil keputusan ketika ada lembaga penyiaran masih berupa berupa meminta klarifikasi kepada lembaga penyiaran yang melanggar. Jika masih melakukan hal yang sama KPID Yogyakarta akan melakukan tindakan selanjutnya yaitu memberikan sanksi admisitratif berupa teguran tertulis.

\section{Sanksi KPID}

Lembaga penyiaran dalam menyiarkan siaran iklan niaga dan siaran iklan layanan masyarakat wajib mematuhi waktu siar dan persentase yang diatur dalam peraturan perundang-undangan. Lembaga penyiaran dapat diminta pertanggung jawabannya, apabila mereka melakukan perbuatan yang melanggar peraturan perundang-undangan. Sanksi yang diberikan dapat dijatuhkan kepada korporasi, maupun kepada pengurus korporasi tersebut. ${ }^{\mathbf{1 2}}$

Selain itu Sanksi dari KPID DIY yaitu Program siaran yang terbukti secara sah dan meyakinkan melanggar Standar Program Siaran dijatuhkan sanksi administratif oleh KPI, sesuai dengan Peraturan Gubernur Nomor 38 Tahun 2017 tentang tata acara pengenaan sanksi administratif dan pemberan penghargaan atas penyelenggaraan penyiaran yaitu

a. Teguran tertulis, Sanksi administratif berupa teguran tertulis pertama dan kedua atas pelanggaran yang dilakukan oleh lembaga penyiaran paling sedikit selama 7 (tujuh) hari kalender.

b. Penghentian sementara mata acara yang bermasalah dikenai sanksi administratif berupa penghentian sementara mata acara yang bermasalah setelah melalui tahap tertentu. Selama waktu pelaksanaan sanksi administratif penghentian sementara berlangsung, lembaga penyiaran dilarang menyajikan program siaran dengan format sejenis pada waktu siar yang sama atau waktu yang lain dalam beberapa hari sesuai pelanggaran yang dilakukan lembaga penyiaran.

c. Pembatasan durasi dan waktu siaran Pembatasan durasi dan waktu siaran mata acara yang bermasalah setelah melalui tahap teguran tertulis dan penghentian sementara mata acara yang bermasalah, Lembaga penyiaran ketika sedang melaksanakan sanksi pembatasan durasi dan waktu siaran yang telah ditentukan

\footnotetext{
${ }^{12}$ Evi Deliana Hz, "Perlindungan Hukum Terhadap Anak Dari Konten Berbahaya Dalam Media Cetak Dan Elektronik", Vol.3, No.1, Jurnal Ilmu Hukum,Fakultas Hukum Universitas Riau, 2012, hlm.17
} 
oleh KPID DIY dilarang menampilkan mata acara yang melanggar dengan waktu full seperti biasa, namun ada batasan waktu yang telah ditentukan sesuai ketentuan yang ditetapkan.

d. Denda Administratif, Setelah mendapat teguran tertulis sebanyak 2 (dua) kali, maka KPI akan melayangkan surat kepada lembaga penyiaran yang melanggar dalam rangka dikenai sanksi administratif berupa denda administratif untuk jasa penyiaran radio paling banyak Rp.100.000.000,- (seratus juta rupiah) dan untuk jasa penyiaran televisi paling banyak Rp 1.000.000.000,- (satu miliar rupiah) sesuai ketentuan ketika persidangan yang memiliki hukum tetap sesuai dengan pelanggaran yang dilakukan lembaga penyiaran.

e. Pembekuan kegiatan siaran untuk waktu tertentu, Sanksi administratif pembekuan kegiatan siaran untuk waktu tertentu dan juga sanksi administratif yaitu dengan KPI akan melayangkan surat undangan kepada lembaga penyiaran yang melanggar dalam rangka untuk mendengarkan pendapat apakah lembaga penyiaran yang bersangkutan untuk memberikan klarifikasi atas pelanggaran yang telah dilakukan. Setelah itu dikenai pencabutan izin penyelenggaraan penyiaran hanya dapat dilakukan setelah adanya putusan pengadilan yang memperoleh kekuatan hukum tetap, dalam penentuan sanksi akan tergantung pada subyektivitas komisioner KPI.

f. Tidak diberi perpanjangan izin penyelenggaraan penyiaran, Lembaga penyiaran yang bersangkutan tidak diberikan izin penyelenggaraan penyiaran ketika Lembaga penyiaran tersebut sudah diberikan surat teguran 1 (satu) dan surat teguran 2 (dua) karena belum mengajukan permohonan perpanjangan izin. Tatacara pengajuan keberatan penjatuhan sanksi admiistratif dengan mengajukan keberatan yang paling lambat dilakukan 3 (tiga) hari kerja sejak diterimanya sanksi tidak diberikan perpanjangan izin penyelenggaraan penyiaran.

g. Pencabutan izin penyelenggaraan penyiaran, Setelah melewati beberapa ketentuan sanski yang ditetapkan KPI namun lembaga penyiaran tidak memperbaiki maka langkah yang terakhir yaitu Pencabutan izin penyelenggaraan penyiaran hanya dapat dilakukan setelah adanya putusan dari pengadilan yang memperoleh kekuatan hukum tetap.

\subsection{Faktor Penghambat Pengawasan Penyiaran Komisi Penyiaran Indonesia Daerah Yogyakarta}

Komisi Penyiaran Indonesia (KPI) yang merupakan organ lapis kedua adalah sebuah lembaga independen yang dibentuk oleh undang undang yang ada di Indonesia yang kedudukannya setingkat dengan lembaga negara lainnya dan berfungsi sebagai regulator penyelenggaraan penyiaran di Indonesia. Sebagaimana yang dimaksud dalam 
Pasal 7 ayat (2) UU No. 32 Tahun 2002 tentang Penyiaran, KPI adalah lembaga negara yang bersifat independen mengatur hal-hal mengenai penyiaran. ${ }^{13}$

Namun dalam perjalanannya kewenangan KPI/KPID DIY sebagai lembaga negara independen tidak tercermin dalam UU No. 32 Tahun 2002 tentang penyiaran, dimana peran KPI dalam merumuskan Peraturan Pemerintah tentang penyiaran dihapus oleh Mahkamah Konstitusi. Putusan MK tersebut menyatakan bahwa KPI tidak dapat bersama dengan pemerintah membentuk Peraturan Pemerintah yang berkaitan dengan penyiaran. MK memutuskan bahwa kewenangan KPI membentuk Peraturan Pemerintah bersama dengan Pemerintah bertentangan dengan Pasal 5 ayat (2) UUD Tahun 1945, yang menyatakan bahwa Presiden menetapkan Peraturan Pemerintah untuk menjalankan undang-undang sebagaimana mestinya. MK berpendapat bahwa peraturan pemerintah merupakan produk hukum yang ditetapkan oleh Presiden. ${ }^{14}$

Selain itu secara kelembagaan KPID DIY masih berada di bawah Dishub kominfo. Anggaran KPID DIY juga masih kecil sehingga berpengaruh juga pada kurangnya fasilitas pengawasan yang dimilikinya. Anggapan bahwa masyarakat DIY merupakan masyarakat yang sangat kritis ternyata belum tercermin karena minimnya partisipasi masyarakat dalam melakukan aduan. Lembaga penyiaran yang sangat berorientasi pada segi komersial dan mengesampingkan nilai edukasi juga menjadi salah satu hambatan. Kemudian pesatnya perkembangan teknologi televisi seperti munculnya sistem siaran digital dan streaming belum dapat diimbangi oleh KPID DIY yang dilakukan selama ini kurang maksimal, sedangkan dasar hukum yang digunakan oleh KPID DIY sudah tidak relevan dengan perkembangan teknologi televisi.

Integrasi yang dilakukan KPID DIY belum berjalan secara maksimal.Adaptasi KPID DIY yang berjalan selama ini belum berjalan efektif dengan minimnya inovasi dalam proses pengawasan yang ada. Berbagai hambatan yang dihadapi oleh KPID DIY meliputi : kendala regulasi yang sudah tidak relevan, masalah struktur kelembagaan yang tidak independen dan keterbatasan finansial, fasilitas pengawasan siaran televisi yang masih kurang dan partisipasi masyarakat DIY yang masih minim, sulitnya meningkatkan kualitas isi siaran dari stasiun televisi yang terlalu mementingkan aspek komersial daripada edukasi, serta pesatnya perkembangan teknologi televisi yang tidak dapat diimbangi oleh kinerja pengawasan KPID DIY. ${ }^{15}$

Komisi Penyiaran Indonesia merupakan Lembaga negara yang memfasilitasi masyarakat untuk menyalurkan aspirasinya dan mewakili kepentingan masyarakat agar

\footnotetext{
${ }^{13}$ Irzha, Friskanov. "Kedudukan dan Kewenangan Komisi Penyiaran Indonesia Daerah (KPID) Atas Hak Publik dalam Penyelenggaraan Penyiaran di Provinsi Sulawesi Tengah" Vol.1 No.1, 2016 hlm 78

${ }^{14}$ Doly, Denico "Upaya Penguatan Kelembagaan Komisi Penyiaran Indonesia Dalam Perspektif Hukum" Jurnal Negara Hukum, Vol.6 No.2, 2015 hlm 151

${ }^{15}$ Subaktio, Hendry dan Ida Rachmah, 2012, Komunikasi Politik, Media dan Demokrasi, Jakarta, Kencana Prenada Media Group, hal. 45
} 
terciptanya program siaran yang bermutu dan mendidik, selain itu KPID DIY juga menjembatani kepentingan masyarakat dengan institusi pemerintah dan juga lembaga penyiaran.

Oleh karena itu berdasarkan kewenangan menurut Undang-Undang No 32 tahun 2002 tentang Penyiaran. Pemantauan, Aduan dan Hasil Analisi, dalam rangka menjalankan peran dari KPID DIY memiliki kewenangan dalam mengatur segala hal mengenai penyiaran yang dimaksudkan untuk mengatur tatanan dalam penyiaran di Indonesia yang bermutu dan juga mendidik. Selain itu dalam perannya KPID DIY juga wajib menindak lanjuti dari aduan maupun kritik, saran dari masyarakat yang bertujuan untuk memeperbaiki tatanan dari penyiaran.

Lembaga Penyiaran baik televisi maupun radio merupakan media yang sangat berpengaruh dalam kehidupan masyarakat, setiap orang juga menggunakan media televisi atau radio dalam hal untuk mendapatkan suatu informasi yang diinginkan dan hiburan. Perkembangan teknologi tentunya juga mendorong perkembangan dan juga perluasan informasi yang semakin cepat, oleh karena itu Lembaga penyiaran sangatlah penting dalam pengembangan potensi sosial budaya dan juga potensi dari masyarakat itu sendiri.

Namun demikian, tidak dapat dipungkiri bahwa media penyiaran juga dapat berdampak negatif bagi masyarakat apabila tidak mendapatkan filter dana pengawasan yang baik dari KPID DIY yang merupakan Lembaga independent yang mempunyai tugas, wewenang dan juga kewajiban dalam terselenggaranya penyiaran yang baik dan bermutu. Namun tidak semata-mata tugas Lembaga penyiaran yang bertanggung jawab namun sebagai masyarakat juga haruslah aktif dalam pengawasan siaran televisi maupun radio, yang khususnya televisi.

Kerjasama dari KPID dan Masyarakat yaitu masyarakat bisa mengadukan isi siaran yang menurut pandangan masyarakat bertentangan dengan Standar Program Siaran dan juga dapat berperan serta dalam mengawasi isi siaran, aduan masyarakat tersebut bisa tersalurkan dalam bentuk surat aduan yang dapat dikirimkan kepada KPID. ${ }^{16}$ Hal tersebut dapat membantu KPID dalam mengawasi program siaran demi tercapainya penyiaran yang bermutu dan berkualitas untuk masyarakat.

Komisi Penyiaran Indonesia Daerah Istimewa Yogyakarta ( KPID DIY ) merupakan suatu wadah aspirasi untuk masyarakat dan merupakan wakil dari kepentinganya dalam hal penyiaran ${ }^{17}$, aspirasi masyarakat tersebut yang berkaitan dengan isi siaran maupun aduan serta kritik dan saran yang dapat disalurkan kepada Lembaga negara KPID DIY. Sesuai dengan Pasal 2 ayat (1) Peraturan Daerah Nomor 13 tahun 2016 pasal 2 ayat 1 bahwa pengaturan Penyelenggara Penyiaran berdasarkan

\footnotetext{
${ }^{16}$ Sjuchro, Wardiana Dian "Pelaksanaan Regulasi Penyiaran Daerah Studi di Sepuluh Provinsi”. Vol.1 No.1 , 2017 hlm.78

${ }^{17}$ Primasanti, Studi Eksplorasi Sistem Siaran Televisi Berjaringan di Indonesia, Jurnal Ilmiah Scriptura, Vol. 3 No. 1, 2009 hlm.66
} 
asas : (1) Manfaat (2) Adil dan Merata (3) Kepastian Hukum (4) Keamanan (5) Kemitraan (6) Etika (7) Kemandirian (8) Kebebasan (9) Tanggung jawab. Oleh karena itu Peran serta Masyarakat sangat dibutuhkan dalam menciptakan Program Siaran yang berkualitas untuk masyarakat itu sendiri, sesuai dengan Pasal 21 Peraturan Daerah Nomor 13 tahun 2016 pada Bab VI Peran serta masyarakat yaitu :

(1) Setiap orang atau kelompok masyarakat dapat berperan serta dalam pengawasan program siaran

(2) setiap orang atau kelompok masyarakat dapat mengajukan keberatan terhadap program siaran yang bertentangan dengan norma

(3) keberatan sebagaimana yang di maksud pada ayat 2 diajukan dalam bentuk pengaduan tertulis ke KPID.

Oleh karena itu kekuatan KPID DIY itu sendiri yaitu :

a. Sebagai Lembaga negara independent yang sah dan mempunyai kewenangan dalam mengatur penyiaran.

b. Keterbukaan informasi yang diberikan dalam hal mendistribusikan informasi yang ideal kepada masyarakat.

Sedangkan Kelemahan KPID sendiri ialah :

a. Sebagai Lembaga negara yang bergerak di bidang penyiaran KPID DIY masih belum tegas dalam menanggapi aduan yang di kirimkan oleh masyarakat kepada stasiun televisi yang menayangkan konten yang menurut masyarakat merugikan. Masih maraknya tayangan pornografi, kekerasan, dan juga pengobatan alternatif yang tidak mendidik atau keluar dari ketentuan.Kurangnya tenaga pemantau serta alat rekam sehingga seringkali kelewatan mendata pelanggaran yang ada di program siaran televisi maupun radio.

b. Tidak optimalnya kerja dari komisioner yang disebabkan oleh masa jabatan yang diamanahkan hanya tiga tahun.

c. Sanksi administratif yang terdapat di Pasal 55 ayat 2 dalam praktiknya relatif lama sehingga mendindaklanjutinya dan juga pemberian sanksi tidak dapat langsung ditangani dengan cepat.

Sedangkan sarana pemantau isi siaran yang masih kurang berupa alat perekam isi siaran merupakan suatu masalah tersendiri dalam pelaksanaan Pasal 16 Perda DIY No. 13 Tahun 2016 Tentang Penyelenggaraan. Alat perekam isi siaran televisi yang terdapat di KPID DIY hanya berjumlah 7, hal ini tidak sebanding dengan jumlah stasiun televisi yang ada di Yogyakarta. Selain alat perekam yang masih kurang, televisi sebagai perlengkapan yang penting dalam mendukung implementasi Perda juga masih kurang. Dalam bidang pengawasan isi siaran hanya terdapat 7 televisi untuk memantau isi siaran. 
Kurangnya staf tenaga pemantau dan perlengkapan pemantauan menjadi hambatan bagi KPID DIY dalam mengimplementasikan kinerja KPID. Kurangnya staf tenaga pemantau berdampak pada tidak efektifnya pemantauan yang dilakukan karena tidak semua stasiun televisi dapat dipantau secara bersamaan. Sedangkan kurangnya perlengkapan pemantauan untuk merekam semua isi siaran stasiun televisi maupun radio yang ada di Jogja harus dilakukan secara bergantian yang pemantauan untuk merekam semua isi siaran stasiun televisi maupun radio yang ada di Jogja harus dilakukan secara bergantian yang mengakibatkan kurang maksimal pengawasan yang dilakukan karena bisa saja ada pelanggaran yang dilakukan oleh stasiun televisi maupun radio saat siaran tidak direkam.

\section{Simpulan}

\subsection{Simpulan}

Berdasarkan uraian hasil penelitian pemabahasan di atas dapat ditarik kesimpulan bahwa pengawasan penyiaran dilaksanakan dalam tahap awal yaitu sosialisasi kepada lembaga penyiaran yang ada di Yogyakarta. Sosialisai yang dilakukan oleh KPID DIY dalam bentuk literasi media, diskusi publik, dan talkshow di radio maupun televisi sedangkan sosialisasi yang membahas tentang Perda Penyelenggaraan Penyiaran dilakukan dua bulan sekali. Namun, implementasi Perda ini belum sampai ke tahap pemberian sanksi karena masih banyaknya stasiun televisi berjaringan yang ada di Yogyakarta berbeda persepsi mengenai program siaran lokal yang dimaksud dalam Perda Peyelenggaraan Penyiaran sehingga hal ini membuat implementasi Perda tersebut masih dalam tahap sosialisasi dan pembinaan kepada stasiun televisi berjaringan agar tidak terjadi perbedaan persepsi lagi. Perkembangan sebagian besar stasiun televisi berjaringan yang ada di Yogyakarta belum sepenuhnya memenuhi kebutuhan masyarakat lokal seperti yang telah diatur dalam peraturan perundang-undangan maupun Perda DIY No. 13 Tahun 2016 tentang Penyelenggaraan Penyiaran. Hal ini terlihat dari masih banyaknya stasiun televisi berjaringan yang belum memenuhi kewajiban menyiarkan program siaran lokal dengan durasi minimal 10\% dari durasi siar per hari pada jam 05.00 sampai 22.00 WIB seperti yang telah diatur dalam pasal 16.

Maka dapat ditarik kesimpulan faktor-faktor pendukung dan penghambat implementasi kinerja Penyelenggaraan Penyiaran. Berikut faktor pendukung implementasi kinerja KPID :

a. Adanya komitmen dari KPID DIY. Dukungan para pelaksa Perda dapat dilihat dari komitmen komisioner KPID DIY untuk melaksanakan Perda Penyelenggaraan Penyiaran. Hal ini dapat dilihat dari segi kedisiplinan komisioner baru yang setiap hari selalu hadir di kantor, dan selain itu juga komisioner baru telah melakukan kunjungan ke lembaga penyiaran dan sosialisasi berupa literasi media baik kepada 
masyarakat, lembaga penyiaran, maupun mahasiswa melalui talkshow di stasiun televisi maupun radio.

b. Adanya dukungan dari Pemerintah Daerah. Alokasi anggaran berupa dana hibbah yang berasal dari Anggaran Penetapan dan Belanja Daerah (APBD) merupakan dukungan dari Pemerintah Daerah serta adanya fasilitas berupa kantor KPID DIY karena tanpa adanya kantor maka KPID DIY tidak bisa melakukan koordinasi untuk melaksanakan Perda.

c. Adanya wewenang. KPID DIY dalam mengimplementasikan Peraturan Daerah ini memiliki wewenang untuk mengeluarkan surat tertulis yang diberikan kepada lembaga penyiaran yang melanggar. Selain telah diatur dalam Peraturan Daerah No. 13 Tahun 2016 tentang Penyelenggaraan Penyiaran, wewenang KPID DIY juga diatur dalam Peraturan Gubernur DIY No. 38 Tahun 2017 tentang Tata Cara Pengenaan Sanksi Administrasi dan Pemberian Penghargaan atas Penyelenggaraan Penyiaran.

d. Adanya SOP untuk melaksanakan Perda dan koordinasi yang jelas antara KPID DIY kepada pemerintah maupun KPID DIY kepada lembaga penyiaran.

\subsection{Saran}

KPID DIY harus lebih tegas untuk menegur lembaga penyiaran jika lembaga penyiaran tersebut memang melakukan pelanggaran. Walau dalam hal ini KPID DIY hanya memiliki wewenang dalam memberikan sanksi administrasi, namun KPID DIY dapat memberikan rekomendasi buruk kepada lembaga penyiaran yang melanggar izin siarnya tidak diperpanjang. Tentunya hal ini dapat memberikan efek jera kepada lembaga penyiaran yang melanggar sehingga semua lembaga penyiaran akan takut melakukan pelanggaran. KPID DIY hendaknya menambah anggota tenaga pemantau dalam bidang pengawasan isi siaran agar KPID DIY dapat memaksimalkan tugasnya untuk mengawasi program siaran lokal yang disiarkan oleh stasiun televisi berjaringan. KPID DIY hendaknya menambah televisi dan alat perekam isi siaran agar tidak dilakukan secara bergantian yang mengakibatkan kurang maksimal pengawasan yang dilakukan karena bisa saja ada pelanggaran yang dilakukan oleh stasiun televisi saat siaran tidak direkam dan KPID DIY tidak dapat merekam dan menghitung jumlah durasi program siaran lokal yang disiarkan oleh stasiun televisi berjaringan yang pada saat itu tidak direkam. KPID DIY hendaknya meningkatkan sosialisai mengenai Peraturan Daerah DIY No. 13 Tahun 2016 tentang Penyelenggaraan Penyiaran kepada lembaga penyiaran untuk meminimalisir terjadinya perbedaan persepsi antara KPID DIY dengan lembaga penyiaran.

\section{Daftar Pustaka}

\section{Buku}

Apriadi Tamburaka, 2013, Literasi Media, Jakarta, PT Rajagrafindo Persada 
Hendry Subaktio dan Ida Rachmah, 2012, Komunikasi Politik, Media dan Demokrasi, Jakarta, Kencana Prenada Media Group.

Onong Uchjana Effendy,M.A, 1993, Televisi Siaran Teori dan Praktek ,Bandung, Mandar Maju

Sutisno P.C.S., 1993, Jakarta, Pedoman Praktis Penulisan Skenario Televisi dan Video, PT Grasindo.

Werner J. Severin \& James W. Tankard,Jr, 2011, Teori Komunikasi, Jakarta,Kencana Prenada Media Grup

\section{Jurnal}

Akibu, Rifka S., Implementasi Kebijakan Perizinan Penyiaran Televisi Lokal di Provinsi Gorontalo, Jurnal Ilmu Administrasi, Vol.4 No.2, 2015

Doly, Denico.Upaya Penguatan Kelembagaan Komisi Penyiaran Indonesia Dalam Perspektif Hukum, Jurnal Negara Hukum, Vol.6 No.2, 2015

Eko, Harry Susanto, Media Massa, Pemerintah dan Pemilik Modal, Jurnal Komunikasi, Vol. 1 No. 6, 2013

Evi Deliana Hz, "Perlindungan Hukum Terhadap Anak Dari Konten Berbahaya Dalam Media Cetak Dan Elektronik" , Jurnal Ilmu Hukum,Fakultas Hukum Universitas Riau, Vol2012

Irzha, Friskanov. Kedudukan dan Kewenangan Komisi Penyiaran Indonesia Daerah (KPID) Atas Hak Publik dalam Penyelenggaraan Penyiaran di Provinsi Sulawesi Tengah, Jurnal Hukum, Vol.1 No.1, 2016

Febri, Eko Prasetyo Peran Komunikasi Dalam Mengoptimalkan Komisi Penyiaran Indonesia Daerah (KPID) Provinsi Kalimantan Timur Dalam Melakukan Pengawasan Terhadap Lembaga Penyiaran di Samarinda, Jurnal Ilmu Komunikasi, Vol.5 No.4, 2017

Primasanti, Studi Eksplorasi Sistem Siaran Televisi Berjaringan di Indonesia, Jurnal Ilmiah Scriptura, Vol. 3 No. 1, 2009

Sjuchro, Wardiana Dian "Pelaksanaan Regulasi Penyiaran Daerah Studi di Sepuluh Provinsi". Vol.1 No.1 , 2017

Media, Sucahya, Teknologi Komunikasi dan Massa, Jurnal Komunikasi Vol.2 No. 1, 2013

Wahyuni, Decy. Dkk. "Manajemen Dan Kebijakan Operasional Televisi Nasional Berbasis Lokal Di Kota Makassar". Jurnal Komunikasi KAREBA, Vol. 3 No.3, 2014

Yantos. Peranan Lembaga Penyiaran Publik Lokal Dalam Mendukung Pemerintah Daerah, Jurnal Risalah, Vol.26 No.2, 2015

\section{Regulasi}

Undang-Undang nomor 32 tahun 2002 tentang Penyiaran

Undang-Undang Dasar Negara Republik Indonesia Tahun 1945.

Undang-undang No. 40 Tahun 1999 tentang Pers

Undang-undang No.14 Tahun 2008 tentang Keterbukaan Informasi Publik Pedoman Perilaku Penyiaran (P3) dan Standar Program Siaran (SPS)

Peraturan Daerah Daerah Istimewa Yogyakarta Nomor 13 Tahun 2016 Tentang Penyelenggaraan Penyiaran 
Peraturan Gubernur Daerah Istimewa Yogyakarta No. 37 Tahun 2017 tentang Fasilitasi Pembentukan Lembaga Penyiaran Komunitas

Peraturan Gubernur DIY No. 38 Tahun 2017 tentang Tata Cara Pengenaan Sanksi Administrasi dan Pemberian Penghargaan atas Penyelenggaraan Penyiaran Sistem Stasiun Jaringan Oleh Lembaga Penyiaran Swasta Jasa Penyiaran Televisi. 